\title{
Children of the Post-communist Period in Contemporary Ukrainian Literature for Young Readers
}

\begin{abstract}
Children of the Post-communist Period in Contemporary Ukrainian Literature for Young Readers. The socio-political transition of the 1990s had a long-lasting impact on children who experienced the collapse of communism and the fall of the Iron Curtain. Contemporary Ukrainian children's and YA literature offers vivid representations of post-communist childhood experiences in Ukraine. Writers like Zirka Menzatiuk and Olena Zakharchenko show emotions and experiences of children and their perception of ideological, cultural and social changes taking place in their society. The child and adolescent protagonists of these narratives grow up being shaped by the events taking place in their country. The generation of children raised in democratic Ukraine is shown as substantially different from older members of Ukrainian society. They are the first "free generation" that professes democratic values, presents active social positions, and defends human rights. Simultaneously, it also cares about their nation's history, culture, and traditions. The article outlines contemporary Ukrainian children's literature devoted to the socio-political transformations of the last 30 years, arguing that some ideological taboos are disappearing and the normative ideas about the behaviour of a growing-up child are changing.
\end{abstract}

Keywords: children, transitional period, post-communist era, contemporary Ukrainian literature for children and young adults, free generation

Дети посткоммунистической эпохи в современной украинской литературе для молодых читателей. Автор статьи предлагает читателям обзор современной украинской детской литературы, посвященной социально-политическим преобразованиям последних 30 лет. Социально-

* Address: Vasyl Stefanyk Precarpathian National University Department of Ukrainian Literature 76000, Ivano-Frankivsk, St. Shevchenko, 57. E-mail: tetiana-kachak@gmail.com. 
политический переход 1990-х годов оказал длительное воздействие на детей, переживших крах коммунизма и падение «железного занавеса». Вопрос детства в посткоммунистической Украине хорошо отражен в современной литературе для детей и молодых взрослых. Такие писатели, как Зирка Мензатюк и Елена Захарченко, демонстрируют эмоции и опыт детей, а также восприятие ими идеологических, культурных и социальных изменений, происходящих в обществе. Дети и подростки, являющиеся главными героями их историй, формируются в результате событий, происходящих в их стране. Поколение детей, воспитанных в независимой Украине, является первым «свободным поколением», которое исповедует демократические ценности, занимает активную гражданскую позицию, защищает права человека, но по-прежнему заботится об истории, культуре и традициях страны.

Ключевые слова: дети, переходный период, посткоммунистическая эпоха, современная украинская литература для детей и молодежи, свободное поколение

\section{Introduction}

After the dissolution of the Soviet Union in 1991, Ukraine became an independent state, yet one suffering from a deep social and economic crisis. The transitional period of the 1990s was marked by the breakdown of the old authoritarian system and the consequent attempts to introduce a new democratic model of social development. These social changes caused the reassessment of values and a search for new models of behaviour. Children and adolescents whose worldviews were formed under the influence of the transformation were the children of the post-communist transitional period, the first free generation that cherished democratic values, wanted to take an active public stand, asserted human rights, and referred to the national history, culture and traditions. Their images (both individual and collective) can be found in the literature for children and young adults, for example in Якя руйнувала iмnepiro (The Way I Was Destroying the Empire, 2014) by Zirka Menzatiuk, Xymip (The Hamlet, 2015) by Olena Zakharchenko, and Вітроломи (The Wind-Breakers, 2015) by Stepan Protsiuk. These authors show children's feelings during the dissolution of the Soviet Union, as well as their ideological, cultural and social awareness of the changes. For contemporary young readers, their works offer not only a historical perspective on the state and nation building, but also a new emotional experience. Even though readers may identify with the young protagonists growing up in the 1990s, for the youngest generation of Ukrainians born after 1991 it is easier to identify with contemporary reality, where almost no allusions to the communist past can be found. Targeted at young readers, the realistic prose by Serhiy Hrydin (Не такий, Незрозумілі, Не-Ангел), Olha Kuprian (Солоні поцілунки), Oksana Lushchevska (Інший дім, Задзеркалля), Nadia Bila (Крута компанія), Dzvinka Matiiash (Марта з вулиці Святого Миколая), Halyna Kyrpa (Мій тато став зіркою) and Mariia Morozenko (Я закохалася) reflect the post-communist paradigm of Ukrainian childhood. The attitudes, moral and ethical issues, as well as the 
expectations concerning the standard behaviour of a growing child are changing; some ideological taboos are disappearing, and in many literary works published now in Ukraine one can find representations of present-day children.

Postcolonial and post-communist studies enable literary scholars to analyse the way literature defines the national identity of young readers, their focus on democratic values and the consequent rejection of totalitarianism and communist ideology. In this context, it is important to mention literary research representing the postcolonial approach while analysing contemporary literature. The first overview of the Ukrainian press and book market for children in the postcolonial perspective was published by Mateusz Świetlicki, who rightly observes that Ukrainian scholars pay too little attention to the importance of literature for children and young adults, which can be treated as one of the key elements in shaping post-communist and postcolonial identities' Comparing children's literature of the Soviet period with books published after gaining independence in 1991, Swietlicki highlights the main problems of the development of the Ukrainian book market for children, such as ideology, censorship, lack of translations, Soviet propaganda, and, more recently, neo-colonial Russification.

Even though reviewers and critics such as Valentyna Vzdulska ${ }^{1}$, Olesia Kopetska $^{2}$, and Tetiana Savchenko ${ }^{3}$ evaluated works written by Zirka Menzatiuk and Olena Zakharchenko, not enough attention has been paid to the rethinking and analysis of the literary portrayals of Ukrainian children and adolescents during the Soviet era. Мy оwn Украӥнська література для дітей та юнацтва (Ukrainian Literature for Children and Youth, 2016) ${ }^{4}$ includes a general analysis and interpretation of the literary works by the aforementioned authors. In this article I would like to argue that the artistic representations of childhood in post-communist societies are worth investigating more thoroughly: I discuss the two most common discourses on post-communist children in contemporary Ukrainian literature for children and youths. The former has appeared in relation to the artistic interpretation of children's experiences of the transitional period from communism to democracy on the basis of their understanding of the country's national revival. The latter discourse has emerged from the artistic portrayal of children who were born and matured in a post-totalitarian and post-communist country. By analysing contemporary fiction for children and young adults I show the main tendencies of the representation of

${ }^{1}$ M. Świetlicki, "Dzieci imperium... - postkolonialny wymiar ukraińskiego rynku książki i prasy dla dzieci i młodzieży," Porównania 15, 2015, pp. 233-244.

2 В. Вздульська, Нове вино в старі міхи: «Як я руйнувала імперію» Зірки Мензатюк, https://starylev.com.ua/club/article/nove-vyno-v-stari-mihy-yak-ya-ruynuvala-imperiyu-zirkymenzatyuk (access: 18.05.2017).

3 О. Копецька, Як я руйнувала імперію любов'ю, https://starylev.com.ua/club/article/yak-yaruynuvala-imperiyu-lyubovyu (access: 19.05.2017).

4 Т. Савченко, “Хутір” Олени Захарченко. Чого я не знала про 24 сериня 1991 року, http:// vysnovky.com/blogs/2203-hutir-oleni-zaharchenko-chogo-ya-ne-znala-pro-24-serpnya-1991-roku (access: 18.05.2017). 
children and childhood in the transitional and post-communist Ukrainian society. Moreover, I discuss how writers understand the attitudes of children and young adults to such issues as national revival, democratisation, and openness to Western culture.

\section{Transitional Children and the National Revival}

Zirka Menzatiuk's $Я \kappa я$ я руйнувала імперію (The Way I Was Destroying the Empire, 2014) is the first Ukrainian literary book for teenagers that depicts the way of life of the Soviet people, their fears and strivings during the last years of the USSR. The main characters are children of the transitional period: Yaryna, the teenage narrator of the story, and her friends from a village in Bukovyna (Western Ukraine), Pivoniia, Igrek, and Mykola. Other important characters include Aunt Orysia, Yaryna's parents, grandmother, and grandfather, who was repressed for his nationalistic ideas. Yaryna and her parents live in Kyiv, but for summer holidays she goes to see her grandmother in Bukovyna. With the other teens, she witnesses the socio-political changes in the country and tries to deal with them.

The transitional children have to live in two social and ideological dimensions: communist and post-communist. When Yaryna and her parents go to Lithuania and attend a meeting for the Lithuanians' right to speak their native language, she learns for the first time about the public opinion on the national revival and breaks free from the communist dogmas. Yaryna's parents are scared to reveal their attitude in order not to be arrested, although they have dreamt of the revival of the Ukrainian language and of the chance to think freely and to express their views.

The narrative relates the origin of Narodnyi Rukh (the nationalistic movement of the Ukrainians for their freedom and independence), young people's participation in the protests against the closure of churches, and their struggle for national interests. The children also take part in such events as lighting candles on the spot where a UPA soldier (a soldier of the Ukrainian Insurgent Army) lost his life; they help to make symbolical Ukrainian items and attend meetings organised by Narodnyi Rukh. They reject communists and the attendants of the Soviet system.

The dissolution of the Soviet Union is treated as a precondition for the country's revival, for the freedom of spirit, and for getting rid of the fear of Soviet power and the communist regime:

The demolition of the Berlin Wall - the wall of silence of a little man who used to be part of the 'great' Soviet people - has caused a public debate on all latent individual and collective frames of mind, wishes, desires, and expectations. ${ }^{5}$

5 Т. Качак, Українська література для дітей: підручник, Київ 2016, pp. 315-316, 322. 
Menzatiuk shows the unique spirit of the national revival and the need for social changes, which also happen in the young heroes' hearts. Yaryna and Orysia share the same ideas:

It felt as if the militia had disappeared, KGB agents (the agents of the National Security Committee in the USSR), the lists of detentions and all dull 'sovdepia' (the soviet style of life), too. There were free people around me and I was free too, I was intoxicated by the unknown, dizzying feeling of freedom! ${ }^{6}$

Moreover, the author accurately depicts the psychological state of the individual and the social euphoria which embraced people after the collapse of the Soviet Union. Zirka Menzatiuk mentions that the disputable and prejudiced reviews of her novel by some literary critics prove "the importance of the artistic re-thinking of the Soviet period, of the peculiarities of the so-called 'sovok' (the Soviet type of mentality) from which, to be frank, we are still suffering"? ${ }^{7}$ The author believes that the totalitarian system is a difficult topic for teenage readers, but by touching upon it in literary works for them, we can change the "sovok way of thinking".

Olena Zakharchenko in Xymip (The Hamlet, 2015) also describes the totalitarian system and the terror Ukrainians had to face. Khrystia, the protagonist of her novel, witnessed her dad being fired for his nationalistic beliefs and her granddad's fear of the political system. Then she saw the upheaval in the Soviet Union and her family's anticipation of Ukraine's long-dreamt independence. Zakharchenko depicts the episodes of the national struggle for independence, but those events are evaluated indisputably: she eulogizes brave Zlata; the endurance of the Ukrainian insurgents; Khrystyna’s granny's and dad's strength of mind; and Khrystia's and Mykolka's devotion and their sense of responsibility.

Khrystia and Mykolka are transitional children who do not always understand what is happening but nevertheless are capable of telling strangers from those of their own kind. Without any hesitation, the children help the soldiers from kryivka. Together they expect changes and wait for news. The author shows a change in the Soviet people's thinking: "The next day it seemed as if something crucial had happened. At night people perished in Moscow. They were crushed by a tank. Thousands of people started to bring flowers and lit candles to that spot?"8 People received what they had been longing for: the communist regime was demolished and finally, Ukraine became independent.

The described events are supposed to teach the young generations of Ukrainians a lesson and to encourage them to become conscious citizens. Ukrainians should be able to defend their independence and democratic values and resist occupants and

${ }^{6}$ Є. Бистрицький, Політологія посткомунізму: Політичний аналіз посткомуністичних суспільств, Київ 1995, http://litopys.org.ua/polpost/pp.htm (access: 18.05.2017).

7 3. Мензатюк, Як я руйнувала імперію, Львів 2014, p. 260.

8 Л. Таран, «Совкова свідомість жива - ї̈ потрібно змінювати». Зірка Мензатюк - про дискусії довкола своєї останньої книжки, День, 2015, no. 106, http://www.day.kiev.ua/uk/article/ ukrayinci-chytayte/sovkova-svidomist-zhyva-yiyi-potribno-zminyuvaty (access: 18.05.2017). 
the totalitarian regime. It goes without saying that the reaction of readers cannot be the same and it may be explained by "a type of regional memory", by socio-cultural, educational, and geographical factors. According to Olena Liubovets:

the level of the national self-identity of the population in Western Ukraine and a pro-Western vector of the socio-cultural orientation influence Western Ukrainians' perception of the historical events and the statesmen in the context of the Ukrainian national interest. Accordingly, the events are seen in the light of their influence on the Ukrainian people's struggle for their freedom and independence. The influence of the particular people and statesmen are also taken into account. That is why most Western Ukrainians remember the Soviet historical period as an occupational one. During this period the Ukrainians' rights and freedoms were abused, the population was repressed or illegally deported. Ukrainian parties and public organizations were not allowed to function. Ukrainian intelligentsia and the Greek Catholic Church were persecuted. The latter has been considered a national church for the last two hundred years. Despite some economic and social success, the majority of the population doesn't see anything positive in the Soviet way of life. Ukraine's future is exclusively connected with the European Union. On the contrary, the population in the East and in the South of Ukraine is distinguished by its bipolarity; they are socially oriented towards Eastern Europe and strive for tight connections with Russia, but not with Western Europe. In the collective memory of the majority of the inhabitants, the historical past, both of the region and of the country, is considered not as a separate, fully independent and self-sufficient process, but as an indispensable part of the Russian and Soviet history. ${ }^{9}$

Such views and beliefs concerning the past and the present are being passed to children in post-communist Ukraine, firstly, by their own social position and attitude to the country, and secondly, by promoting pro-Ukrainian, pro-European, or pro-Russian sentiments.

Knowledge about history and culture which is ideologically free and is gained at the right time plays a crucial role in the establishment of national identity and national memory of the youth. Zirka Menzatiuk has sensibly remarked:

Nowadays, when Ukraine is caught in the whirlpool of tragic events, children are in desperate need of books which would reveal the value of democracy; books which would help children to develop accordingly to the state's social changes. ${ }^{10}$

Fiction is one of the effective means to learn about spiritual and socio-cultural components of national memory because it makes a child think, re-think, and search for the truth, self-determination and national self-identification. The latter manifests itself in the language, behaviour, life principles, as well as moral and ethical standards.

Children of the post-communist era have the opportunity to read about the history which is not falsified and is free from Soviet ideology. Stepan Protsiuk in Вітроломи (The Wind-Breakers, 2015) depicts a contemporary teenager who is contemplating his perception of national history and his affiliation with it:

9 О. Захарченко, Хутір, Львів 2015, р. 179.

10 О. Любовець, “Національна пам'ять в Україні: регіональний аспект," Національна та історична пам'ять 2013, Вип. 6, pp. 117-125, http://nbuv.gov.ua/UJRN/Ntip_2013_6_13 (access: 18.05.2017). 
Maxym has recently learnt about the Ukrainian students' heroic deed near Kruty. ${ }^{11}$ Yes, they all perished. Yes, they could have escaped death. [...] They were like you, Maxym... the dead remain young... there's no need to die for your Motherland, you should live for your Motherland... ${ }^{12}$

This episode serves as an example of how literature and history can influence personality and correct the consequences of the perverted collective memory of the Ukrainian people. In the post-communist era, the experience of one's national and cultural identity becomes an issue of a great importance.

Stepan Protsiuk depicts the generation of transitional children belonging to the post-communist era. He highlights the significance of their upbringing and the difference in values that they can hold. Maxym chooses a conscious national stand and is aware of Ukraine's Soviet past. Most of his peers from Kyiv live in Russian-speaking surroundings and do not care much about the language, cultural issues or the issues of universal injustice. However, everyone is striving for democracy, material wealth, and European living standards. Zirka Menzatiuk, Stepan Protsiuk, and Olena Zakharchenko show the youngest generation of Ukrainians from different perspectives, focusing on their individual and shared behaviours. Taking into account the analysis of the contemporary Ukrainian prose for adolescents, conditionally, we can single out three main types of children belonging to the transitional period. The leading criterion of such a classification is the generation's attitude to life, the level of national self-identification, and their opinion on the Soviet past and post-Soviet present.

The first type refers to children and adolescents who know their national history and have their own attitude towards Ukraine's independence, language, and national culture. They identify as Ukrainians, cherish democratic values and develop strong personalities of great integrity. The second type is represented by those whose viewpoint has been formed under the influence of their parents, who were adherent and subservient to the Soviet system. In such young people's behaviour, the Soviet ideology, the Communist party and the submission to Soviet power for the sake of their own interest prevail over moral and ethical principles common to all. The children and adolescents who are indifferent to national history, culture, and social changes constitute the third type. Nowadays the transitional period (from the Soviet Union to independent Ukraine, from communism to democracy, from the so-called "sovok" to national consciousness and self-identity) is still in progress in Ukraine. This generation was born in the post-communist era, but they felt the consequences of the communist ideology and the Soviet totalitarian regime.

11 Г. Кундіренко, Письменниия Зірка Мензатюк: діти - люди зайняті, "ВВС Ukraine" 4 Dec. 2014, http://www.bbc.com/ukrainian/entertainment/2014/12/141203_book_2014_menzatyuk_int_hk (access: 18.05.2017).

12 The Battle of Kruty took place at the end of January, 1918 near Kruty railway station. Today it is in Chernihiv Oblast, about 130 kilometers northeast of Kyiv. 


\section{Children of the Post-Soviet, Post-Communist Era and the Orientation towards the West}

In the centre of contemporary Ukrainian realistic prose for children and youth, as a rule, there are children, their inner world and surroundings, as well as psychological, social, moral, and ethical issues (such as self-fulfilment, socialization, relations with others, experiences and feelings). At the same time, the issues of social and national character and the issues of "global scale" are left off-screen. If writers describe the transitional children and recollect their own childhood, reproducing the reality of that day with all its social troubles, then, speaking about the generation of today's children, they show those who were born in post-Soviet times in a post-communist society.

In the new reality, accompanied by substantial shifts in the system of basic values, the present-day Ukraine experiences a post-communist era in the newest history, an era which has materialised after the collapse of the Eastern Bloc and the Soviet Union, after the collapse of the communist regimes in those countries. Communism as an ideology (ideological communism) and communism as a particular form of social organisation (real communism) have been defeated in a historical sense and have become irrelevant. Yevhen Bystrytskyi observes that:

The notion 'post-communism' reflects the general feeling of the completion of a certain cultural period. Starting if not with Nietzsche and Heidegger, then with Guardini, Lyotard, Derrida, Eco, some other modern philosophers, this feeling has been fixed by the appearance of widespread images of the end of morality, metaphysics, ideology, the end of the New Era, the project of Modern; in general, this feeling has been accepted in social opinion through the known notion of a postmodernist style. ${ }^{13}$

Literature of the post-communist era is postmodernist and has its own features, including the absence of ideological clichés, clearly pronounced artistic freedom, and disregard for stereotypes, restrictions, and taboos. In children's literature, postmodernism is revealed not only in formal features (the absence of plots, genre diffusion, collage, etc.), but also in plot and functional features. The thematic and problematic range of literature for children is extending; honest, confessional narratives, not only those rich in action, but also those which are psychologically deep, are becoming increasingly prominent. Instructiveness is disappearing, cognitive and educational functions are moving to the background, communicative and entertaining functions are assuming importance; the limits of what is ethical are shifting; the aesthetic paradigm is changing. Thematic freedom is bringing into focus a whole gallery of new images of child characters. These children are distinct from the previous generations because of a different childhood experience.

Some writers highlight the generation gap between those who were brought up on different values and in two worlds - in a Soviet, communist world and a post-

13 С. Процюк, Вітроломи, Київ 2015, pp. 25-26. 
-communist, democratic one. Depicting a child and revealing childhood discourses, the authors are guided by their own reminiscences and represent their communist childhood, which becomes an object of observation and cognition for the contemporary reader. Such an approach can be found in the autobiographical works by Volodymyr Rutkivskyi (Потерчата, 2013) and Olha Slonovska (Дівчинка на кулі, 2012). According to Agnieszka Matusiak, "the postcolonial study is paying a special attention to the historical and psychological discourse of 'finding' the memory of the past with the help of the subjects of postcolonialism? ${ }^{14}$ Contemporary Ukrainian authors are rather critical of this past.

The communist and post-communist practices of creating children's literature differ greatly. In the social and realistic culture of Soviet times, a positive character was depicted as an example to be followed by readers. As rightly stated by Nani Gogokhia:

Considering a child as an object of communist education, the state was trying to fix in him or her those very qualities which were inherent in the official ideology. The image of 'a devoted leninets' (a young follower of Lenin's doctrine - T.K.) having been created for this purpose, presupposed the obligatory behavioural patterns in these or those situations. ${ }^{15}$

The post-communist reality constructs a different image of a child, which is well reflected in contemporary literature, demonstrating various models of breaking from past tendencies: from their rejection, through re-building, to extrapolating from the Western experience. The wish to create life according to the model of the developed Western European countries is a mass social and psychological motive of the post-communist transformations. Such a phenomenon was especially widespread at the beginning of the 1990s, when the economic crisis in the country, inflation, the collapse of the education system and culture, the ideological chaos, and the moral degradation reached its zenith. This period of Ukrainians' social life is well represented in the collection of stories Мама по скаŭny (Mommy via Skype, 2013), edited by Mariana Savka. Children from the stories have been abandoned and left at home by their parents - migrant workers, and the basic values for most of them are money, gadgets, and fashionable clothes. They look up to the Western world and strive for chic life and material welfare of Western civilisation, at the same time neglecting spiritual, cultural, moral, and ethical issues. These issues are vividly illustrated in one of the stories published in Maмa nо скаŭny, Tania Maliarchuk's "Чac дітей" ("Children's Time"). The author shows the influence of social changes, and in particular the economic crisis, on the family and on the education and formation of the child characters.

14 А. Матусяк, "Між мертвою індустрією та молодою демократією. Постколоніальний діалог із минулим у прозі Сергія Жадана,” [в:] А. Матусяк (ред.), Перехресні стежки українського маскулінного дискурсу: Культура й література ХІХ - ХХІ століть, Київ 2014, pp. 307-330.

15 Н. Гогохія, Дитинство у тоталітарному суспільстві: «вірні ленінці» радянської Украӥни y 1930-х роках, http://uamoderna.com/md/gogokhia-childhood-ussr-1930s (access: 18.05.2017). 
Tania Maliarchuk shows collective images of difficult teenagers, abandoned without parental care, who join "a gang", a pack led by the Hrinkovi twins. Their pranks are far from being just jokes or tricks; they are rather acts of aggression, cruelty, and arrogance. The craving for revenge, rivalry, and cynical treatment of other people are typical of the teen characters:

We hated all of us together and each one in particular, we hated ourselves, hated the ruins where we were born; we hated the war which had taken our parents, hated Poland, Italy, Portugal and you, Greece, the far princess of all the countries, was hated the most! ${ }^{16}$

Such feelings do not only illustrate the fact that difficult teenagers are capable of experiencing complex and controversial psychological and emotional states, but that such responses constitute a kind of climax of their anarchic behaviour and the principles they follow. The short story shows a turning point in their lives and inner world; a reaction to social phenomena of a post-totalitarian country.

Both the depiction of children from such a point of view and the investigation of similar psychological, social problems were impossible in social-realistic literature. Writers' freedom to choose main characters and their patterns of behaviour, as well as the plots and formal components of poetic, linguistic, and stylistic solutions, was provoked and caused by the post-communist freedom and guided by its specificity. This specificity envisages

the liberation from the old things without social ideals that are fixed enough and without regulating ideas. That's why the aspiration for stability in a post-communist era is mostly realized in the formation of interim, transitional, situational and accidental forms and norms of social life. ${ }^{17}$

A great deal of modern Ukrainian realistic prose contains the characters of children whose way of thinking was shaped in the post-communist society. They learned about communism and the Soviet way of life from their parents and from the post-Soviet media, culture, and education. This generation was formed under a different, that is non-ideological and non-communist, environment. As a rule, they share modern democratic values; in their behaviour, hobbies, aspirations, and life goals, they have been influenced mostly by the Western world.

Serhiy Hrydin in his Не такий (The Different One, 2013), a story about teenage Denys Potapov, touches upon the problem of socialisation, the process of growing up and the development of children's identity. The reader not only follows the unfolding of the plot but also traces the main hero's identity formation. Presenting the boy's psychological experiences, emotions, and behaviours, as well as highlighting his relations with peers, the author dwells on the topic of the outsider, 'the different one', who is not accepted by the school community and is misunderstood by his parents. Such a topic was absent in children's literature of the communist era. The same concerns

16 Мама по скайпу: збірка оповідань, упорядник Маряяна Савка, Львів 2013, p. 122.

$17 €$. Бистрицький, op. cit. 
Hrydin's Незрозумілі (The Misunderstood, 2016), focusing on teenage misunderstandings with friends, classmates, parents, and teachers. The writer bravely talks about sexual changes and first love. He includes the reminiscences of the first sexual experience connected with the observation of a woman's naked body and the boy's shyness and desire to learn "what it means to be an adult". Such literary works would be definitely eradicated by the ideological censorship of communist society. Finally, Hrydin also uses the boy-teenager motif in Hе-Ангел (Not an Angel, 2016). The main character. Oles, is an ordinary teenager and eighth-grade student, who is dreaming of having a separate room, a new PC, and going to the seaside. He is a good student, has a few friends, enjoys reading but is nevertheless anxious about his parents' constant quarrels, and his mom's disease. Youthful striving for the maximum combined with an acute feeling and burning desire for justice makes Oles a rebel. Rebellion and the right of a child to his or her own point of view and self-assertion is the manifestation of unprejudiced education and of a democratic concept of childhood which has emerged in Ukraine in the last decade.

The characters in Ukrainian literature for children more and more often break free from the didactic instructions and norms. Крута компанія (The Cool Company, 2017) by Nadia Bila is free from any taboos: topical, linguistic, didactic, functional, or ideological. It is an outstanding example of deep, psychological, 'hard-realistic' prose about and for young people who are not adolescents any more, but are not yet adults. Bila's young characters, Milka, Mirka, Karynka, and Yukia Semeniuchka, and also Dimka, Pashka, Oleh, and Sasha Sotnyk, form a diversified group. Each of these characters is a vivid representative of a youth's/ful point of view and behaviour, which is being formed under the influence of their families' social status, the post-Soviet society, and their expanding life experience. Besides, they also have their 'cool companies' where they get tipsy for the first time, have sex, take drugs, and experience hallucinations. Bila's novel is a realistic depiction of post-communist youth culture. This hard realism, already a common convention in Western YA literature, is only now emerging in Ukrainian YA literature.

Such extrapolations of Western literary models have both positive and negative dynamics. Skilful Ukrainian translations of world classical literature and contemporary children's literature, which has gained popularity among readers from various countries, are expanding the literary experience of Ukrainian young readers. The orientation towards the Western experience in creating literature for children in general and the depiction of today's children in particular sometimes acquire the features of a post-totalitarian trauma. It reveals itself in the fact that the works by contemporary Ukrainian writers are discussed in comparison to the works by foreign writers and, at the same time, the conclusion is being made that the former are weaker, or even dull because of the fact that 'adult' topics (death, sex, etc.) have not been deeply investigated, and the main characters are still "decent" in a moral and ethical sense. Here one should see not only the traditions of literature for children and the depiction of a child in it, but also the different attitude to education in 
Ukrainian society. Mateusz Świetlicki rightly states that after 1991 "children of the empire who were raised on Soviet propaganda literature had to face the daunting task of working through their own trauma and raising new generations of postSoviet children". ${ }^{18}$ The moral values of goodness, friendship, mutual help, sympathy, and respect are universal and up-to-date at any time, both in communist and post-communist eras. In his narrative Yurko Tsyrkul, My Friend (Мiй друг Юрко Циркуль, 2010), Valentyn Berdt 'has copied' his characters from real children:

They are my childhood friends who have been transferred from the beginning of the 1980s into the $21^{\text {st }}$ century. And to make them feel comfortable and confident, they've learnt how to use a computer, a smartphone, etc., Yana, my daughter, has helped me. ... It wasn't difficult to accomplish such 'a migration of people' because nothing ever changes in the country of childhood, except for toys and names of sweets. And the moral issues of that time, that is since my childhood, as we see it, haven't lost their topicality at all. On the contrary, they've become even more urgent. ${ }^{19}$

Contemporary writers, as a rule, represent quite a conservative discourse and do not touch upon the limits between moral and ethical norms of children's behaviour, which has been best reflected by school narratives. During the Soviet times, this genre used to be extremely popular. Soviet writers would depict an excellent interaction in a school community between young zhovteniata (young members of the pioneer organisation), pioneers, and komsomoltsi (senior members of the pioneer organisation). Simultaneously, they would present in a negative light those who did not believe in the communist ideals and ideological directives. The school narrative as a genre has not lost its topicality even now, but it has acquired other features. Contemporary pupils, the main characters of novels such as Serhiy Hrydin's Незрозумілі (The Misunderstood, 2016) reflect the real condition of children's and youth culture in contemporary post-communist Ukrainian society. It is no wonder that the subject and the plot triggers are not only classmates' friendship and their unity for the common cause, but also treachery, misunderstanding, disappointment, meanness, and aggression.

The behaviour of contemporary teenagers is usually characterised by emancipation, freedom, and open sexuality, which used to be taboo subjects. Gender and ethical stereotypes are even disappearing from literary works by those authors who lived in Soviet times and until recently have had quite different opinions on the themes appearing in literature for children. Boris Buden observes that:

From their educators the children of communism are getting the instructions also to release their sexuality and loudly declare their sexual identity which has been restrained up to now; the children are being instructed to identify themselves with the secular values unconditionally and instead of being

18 M. Świetlicki, op. cit., p. 237.

19 Валентин Бердт - про літературу для підлітків, http://kazkarka.com/authors-illustrators/ valentyn-berdt-pro-literaturu-dlya-pid.html (access: 18.05.2017). 
obedient subjects to a totalitarian state, the children should become self-conscious, free in their actions, members of a democratic civil society. ${ }^{20}$

The focus on individual and personal issues, self-search, and self-realisation of a young person who is growing up without the pressure to become a cog in the wheel of the social machine, are the features of a post-communist life and of democratic, yet ideologically influenced, literature.

\section{Conclusions}

Targeted at children and adolescents, literary works display life, emotions, worldviews, and behavioural patterns of transitional children. Thanks to the simple language, dynamic plot and vivid characters, readers learn about historical facts and events, evaluating their peers' actions and developing their own understandings of the national self-identity and the process of state building. Zirka Menzatiuk's, Stepan Protsiuk's, and Olena Zakharchenko's main characters become active witnesses to the collapse of the Soviet communist regime and the formation of the Ukrainian nation as a free, democratic society. They represent one of the generations. Another generation consists of children born in the post-communist society, formed under the influence of different factors. Serhiy Hrydin, Olha Kupriian, Nadia Bila, and Mariia Morozenko depict such characters in an artistic, psychologically deep, and true-tolife way. Finally, the child characters in contemporary Ukrainian literature for young readers create an interesting mosaic of children's portraits and characters: it is a kaleidoscope of the discourse of children's culture in a post-communist society.

\section{Bibliography}

Бистрицький, Євген. 1995. Політологія посткомунізму: Політичний аналіз посткомуністичних суспільств [Заг. ред.: Є.Бистрицький]. Київ, Політична думка, http://litopys.org.ua/polpost/ pp.htm (access: 18.05.2017).

Буден, Борис. 2013. Про ідеологію “перехідного суспільства”. Уривок із книги Зона переходу: Про кінець посткомунізму [Переклад з німецької: Неля Ваховська], Київ, Медуза, pp. 34-53, http://ukraine.politicalcritique.org/2015/03/pro-ideologiyu-perehidnogo-suspilstva/ (access: 18.05.2017).

Валентин Бердт - про літературу для підлітків, http://kazkarka.com/authors-illustrators/valentyn-berdt-pro-literaturu-dlya-pid.html (access: 18.05.2017).

Вздульська, Валентина. Нове вино в старі міхи: «Як я руйнувала імперію» Зірки Мензатюк, https://starylev.com.ua/club/article/nove-vyno-v-stari-mihy-yak-ya-ruynuvala-imperiyu-zirkymenzatyuk (access: 18.05.2017).

20 Б. Буден, Про ідеологію «перехідного суспільства» Уривок із книги Зона переходу: Про кінещь посткомунізму [Переклад з німецької: Неля Ваховська], Київ 2013, pp. 34-53, http://ukraine. politicalcritique.org/2015/03/pro-ideologiyu-perehidnogo-suspilstva/ (access: 18.05.2017). 
Гогохія, Нані. Дитинство у тоталітарному суспільстві: «вірні ленінці» радянської України y 1930-х роках, http://uamoderna.com/md/gogokhia-childhood-ussr-1930s (access: 18.05.2017).

Захарченко, Олена. 2015. Хутір. Львів, Видавництво Старого Лева.

Качак, Тетяна. 2016. Украӥнська література для дітей: підручник. Київ 2016.

Копецька, Олеся. Як я руйнувала імперію любов'ю, https://starylev.com.ua/club/article/yak-ya-ruynuvala-imperiyu-lyubovyu (access: 19.05.2014).

Кундіренко, Ганна. “Письменниця Зірка Мензатюк: діти - люди зайняті,” [в:] BBC Ukraine 4 Dec./2014, http://www.bbc.com/ukrainian/entertainment/2014/12/141203_book_2014_ menzatyuk_int_hk (access: 18.05.2017).

Любовець, Олена. 2013. “Національна пам’ять в Україні: регіональний аспект,” [в:] Національна та історична пам'ять. Вип. 6, pp. 117-125, http://nbuv.gov.ua/UJRN/Ntip_2013_6_13 (access: 18.05.2017).

Мама по скайпу: збірка оповідань [упорядник Мар'яна Савка], 2013. Львів.

Мензатюк, Зірка. 2014. Як я руйнувала імперію. Львів, Видавництво Старого Лева.

Матусяк, Агнешка. 2014. “Між мертвою індустрією та молодою демократією. Постколоніальний діалог із минулим у прозі Сергія Жадана, А. Матусяк (ред.), ”Перехресні стежки українського маскулінного дискурсу: Культура й література XIX-XXI століть, Київ, рр. 307-330.

Процюк, Степан. 2015. Вітроломи. Київ, Грані - Т.

Савченко, Тетяна. “Хутір” Олени Захарченко. Чого я не знала про 24 серпня 1991 року, http:// vysnovky.com/blogs/2203-hutir-oleni-zaharchenko-chogo-ya-ne-znala-pro-24-serpnya-1991roku- (access: 18.05.2017).

Świetlicki, Mateusz. 2015. "Dzieci imperium... - postkolonialny wymiar ukraińskiego rynku książki i prasy dla dzieci i młodziė̇y," Porównania 15, pp. 233-244.

Таран, Людмила. 2015. “Совкова свідомість жива - іï потрібно змінювати. Зірка Мензатюк про дискусії довкола своєї останньої книжки” День, no. 106, http://www.day.kiev.ua/uk/article/ ukrayinci-chytayte/sovkova-svidomist-zhyva-yiyi-potribno-zminyuvaty (access: 18.05.2017).

Accepted for publication: 25.09 .2017

Miscellanea Posttotalitariana Wratislaviensia 7, 2017

(C) for this edition by CNS 